\title{
EXPERIMENTAL STUDY
}

\section{The in vitro secretion of human leptin is gender-dependent but independent of the body mass index of the donors}

\author{
Carmela Menendez, Roberto Baldelli, Mary Lage, Xesus Casabiell, Veronica Piñero, Juan Solar ${ }^{2}$, Carlos Dieguez ${ }^{1}$ \\ and Felipe F Casanueva \\ Department of Medicine, Molecular Endocrinology Section and ${ }^{1}$ Department of Physiology, Santiago de Compostela University, Spain and ${ }^{2}$ Division of \\ General Surgery, Hospital de Conxo, Complejo Hospitalario Universitario de Santiago, Spain \\ (Correspondence should be addressed to F F Casanueva, PO Box 563, Santiago de Compostela E-15780, Spain; Email: melage@usc.es)
}

\begin{abstract}
Objective: Leptin is an adipocyte-secreted hormone acting as a signal to the central nervous system, where it regulates energy homeostasis and neuroendocrine processes. Leptin plasma levels are mainly regulated by the percentage of body fat, but are also controlled by several metabolic and nutritional variables. Data regarding leptin secretion suggest that it is gender regulated, and higher levels are present in women than men; however, the biological basis for this sex-related difference is unknown. To clarify those points, a systematic study with tissue cultures from human omental adipose tissue was performed.

Design and methods: Surgically obtained samples from 137 patients (68 women, 69 men) were evaluated. The assay was standardized in periods of $24 \mathrm{~h}$ ending at $96 \mathrm{~h}$. Each adipose tissue sample from a single donor was incubated in triplicate and leptin results expressed as the mean of the integrated secretion into the medium (nanograms of leptin/g tissue per time).

Results: Tissue adipose cultures showed a steady leptin secretion throughout the $96 \mathrm{~h}$ studied, with the peak of secretory activity reached at $48 \mathrm{~h}$; afterwards, the in vitro secretion reached a plateau state. Spontaneous leptin secretion in the $24 \mathrm{~h}$ and $48 \mathrm{~h}$ period, as well as the area under the curve analyzed in the $0-48 \mathrm{~h}$ period, showed a gender-based difference that was significantly $(P<0.05)$ higher in women than in men. When data of spontaneous leptin secretion were correlated with the body mass index (BMI) of the donors, no correlation was found. This suggests that in vivo leptin levels are dependent on the total amount of fat of the individual, but independent of the leptin secretory rate by the adipose tissue of the donor.

Conclusions: Leptin secretion from omental adipose tissue in vitro is: (i) significantly higher in samples from women than in samples from men; and (ii) not correlated with the BMI, showing that in vitro leptin secretion is not related to the adiposity of the donor.
\end{abstract}

European Journal of Endocrinology 143 711-714

\section{Introduction}

Leptin, the ob gene product, is a 167-amino acid hormone secreted by adipocytes with a predicted tertiary structure resembling that of cytokines (1-7). It acts as an afferent satiety hormone to the hypothalamus signaling the amount of body fat stores $(8-11)$ and then regulating appetite, weight gain and fat deposition (12). Leptin plasma levels correlate mainly with the adipose tissue stores. But it is not a simple relationship: its levels increase in parallel to the volume of adipose stores, which would seem to suggest an exponential increase with increasing fat mass. Moreover, the decrease in circulating leptin in fasting is disproportionate to the reduction in fat mass (13). Since leptin levels are correlated with metabolic function, the participation of leptin in new physiologic and pathologic processes has been described, such as the regulation of growth hormone secretion, thyroid hormones and glucocorticoids, reproductive function and angiogenesis (13-15). In addition, glucocorticoids and insulin stimulate leptin synthesis from the adipose tissue, whereas adrenergic activation and testosterone induce an inhibition (16-18). Furthermore, we have recently demonstrated that low temperatures reduce leptin secretion by acting directly on the adipose tissue (19). It is important to emphasize that leptin levels present noteworthy gender differences, with higher levels in women than in men; this difference is evident even from the first hour of life $(20,21)$. At present, no biological explanation has been proposed for these remarkable gender differences.

The aim of the present study was first to confirm if the gender differences in spontaneous leptin secretion could be observed in vitro, in a large series of adipose tissue samples, and secondly to evaluate the role of the 

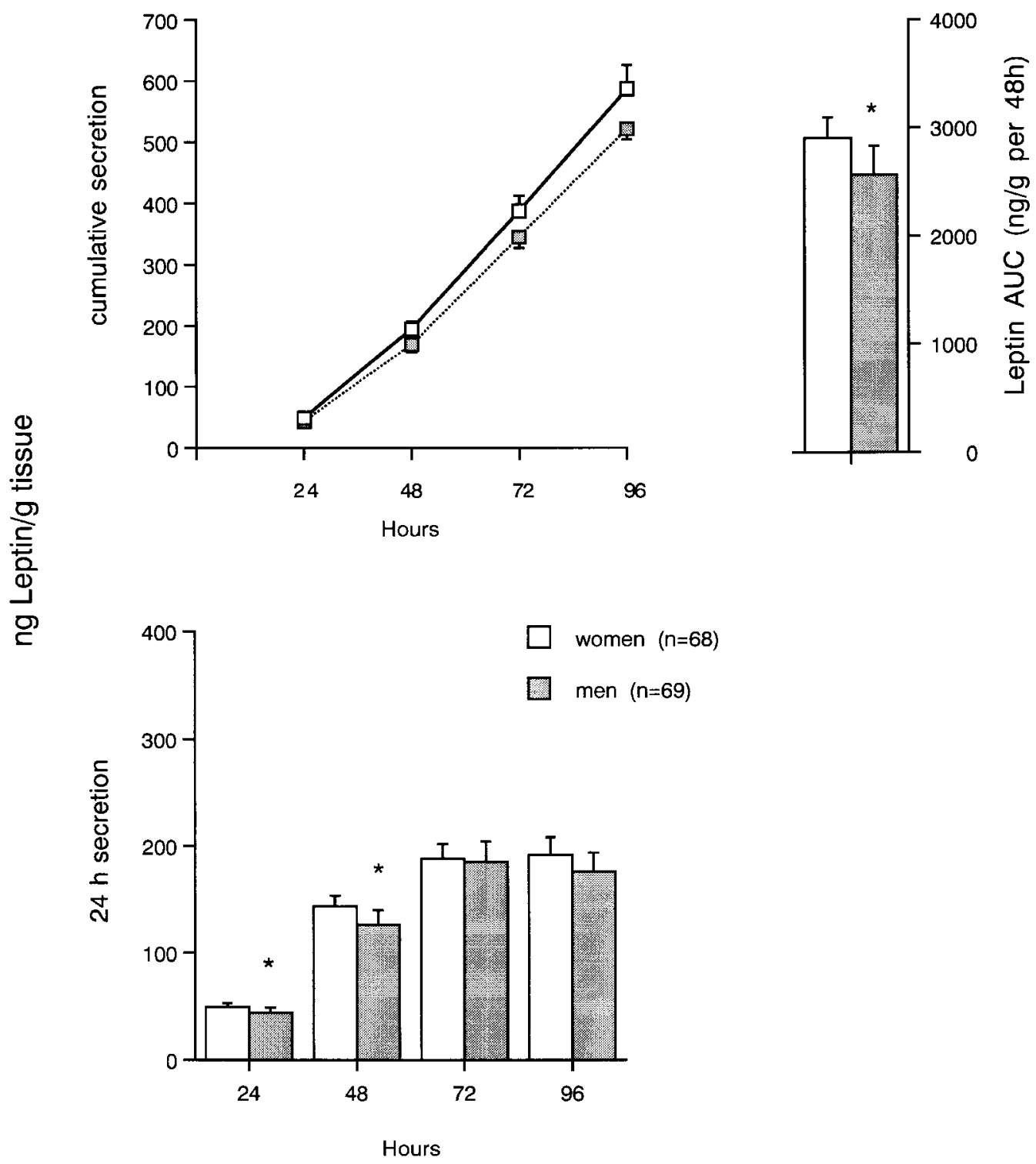

Figure 1 Means \pm S.E. of spontaneous leptin secretion into the incubation medium from omental adipose tissue samples of 68 women and 69 men. Tissue samples from each subject were incubated in triplicate, and values are presented as either $24 \mathrm{~h}$ incubation period (bars), cumulative release to the medium (lines) or AUC (bars). ${ }^{*} P<0.05$ vs women for secretion in the same period.

body mass index (BMI) of donors in the in vitro leptin secretion of the samples.

\section{Materials and methods}

Omental adipose tissue was obtained from 137 patients during elective abdominal surgery; the group was composed of 68 females (age 61.9 \pm 2.0 ; BMI $27.0 \pm$ 0.5 , range 19.5-37.2) and 69 males (age 62.3 \pm 1.9 ; BMI 26.6 \pm 0.4 , range 18.0-35.3). Patients were taking no drugs or antibiotics at the time of abdominal surgery and the presence of malignancy was an exclusion criterion. The study was approved by the hospital ethics committee, and each participating subject provided informed consent. All patients were admitted to hospital for elective abdominal surgery.

In vitro leptin secretion was evaluated as previously described (20). In brief, excised adipose tissue was immediately transported to the laboratory in ice-cold Krebs-Ringer-Hepes buffer ( $\mathrm{NaCl}, 125 \mathrm{mmol} / \mathrm{l} ; \mathrm{KCl}$, $5 \mathrm{nmol} / \mathrm{l} ; \mathrm{MgSO}_{4}, 1.2 \mathrm{nmol} / \mathrm{l} ; \mathrm{CaCl}_{2}, 2 \mathrm{mmol} / \mathrm{l} ; \mathrm{KH}_{2} \mathrm{PO}_{4}$, $1.2 \mathrm{mmol} / \mathrm{l}$; glucose, $6 \mathrm{mmol} / \mathrm{l}$; Hepes, $25 \mathrm{mmol} / \mathrm{l}$; $\mathrm{pH}$ 7.4). After removing blood vessels and connective tissue, adipose tissue was washed with sterile Krebs-RingerHepes and cut into small pieces with sharp scissors. Tissue fragments were placed in six-well dishes (300-400 mg adipose tissue per well) containing $2.5 \mathrm{ml}$ Dulbecco's modified Eagle's medium plus $0.5 \%$ fetal calf serum, 


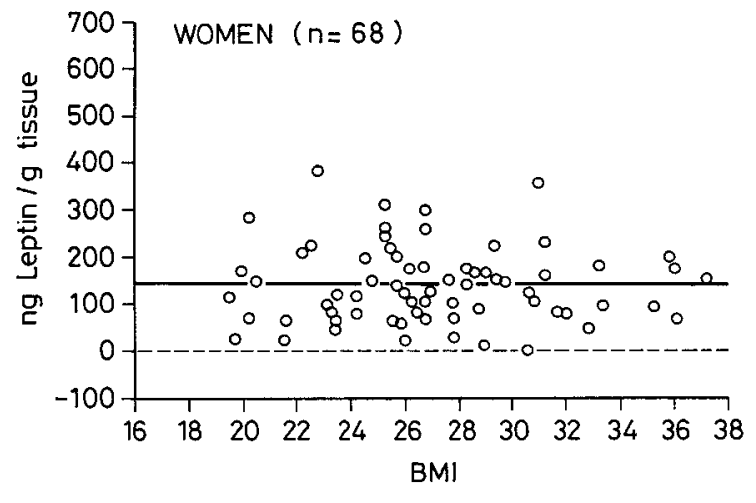

$R=0.010 \quad P=0.935$

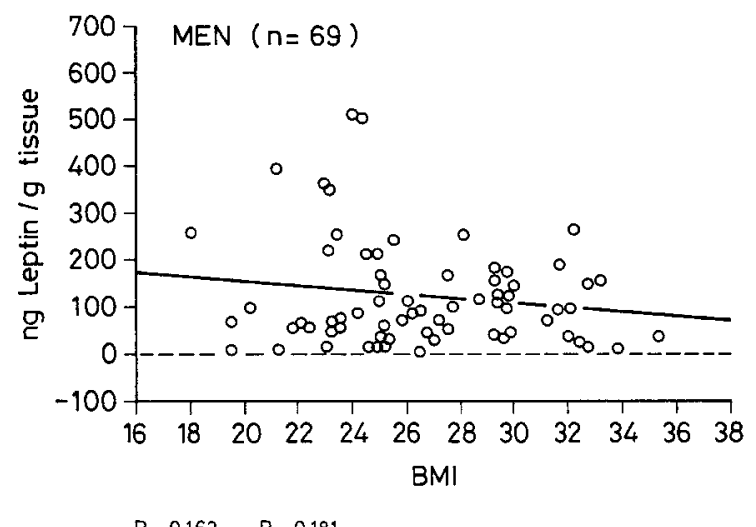

Figure 2 Scatter analysis of leptin secretion at $48 \mathrm{~h}$ vs BMI in 68 women and 69 males. Similar results were observed when analyzing the leptin secretion at 24,72 and $96 \mathrm{~h}$.

supplemented with penicillin $(100 \mathrm{U} / \mathrm{ml})$ and streptomycin sulfate $(100 \mu \mathrm{g} / \mathrm{ml})$. After a preincubation period of $1 \mathrm{~h}$ at $37{ }^{\circ} \mathrm{C}$ under a humidified atmosphere of $95 \%$ air$5 \% \mathrm{CO}_{2}$, the media were aspirated and $2.5 \mathrm{ml}$ fresh medium were dispensed into each well. Culture media were then collected every $24 \mathrm{~h}$ and replaced with fresh medium.

The adipose tissue from a given subject was independently incubated in triplicate and the medium was collected and analyzed every $24 \mathrm{~h}$ to obtain: the $24 \mathrm{~h}$ secretion, the cumulative secretion until $96 \mathrm{~h}$ and the integrated secretion (area under the curve (AUC)) at different time periods. Samples were stored at $-20{ }^{\circ} \mathrm{C}$ until leptin assay. Leptin levels were measured by RIA using commercial kits (Human Leptin RIA; Linco Research Inc., St Charles, MO, USA). The limit of sensitivity was $0.5 \mu \mathrm{g} / \mathrm{l}$, the intraassay coefficient of variation was $8.3 \%$ and the interassay coefficient of variation was $6.2 \%$.

\section{Statistical analysis}

The mean BMI, defined as weight in kilograms divided by the square of the height in meters, was calculated. Leptin secretion was expressed as the total amount of leptin secreted into the well by a given sample (in nanograms) divided by the amount of fat tissue of the sample at the time considered, i.e. ng leptin/g tissue per $24 \mathrm{~h}$. The integrated AUC was calculated by the trapezoidal method. Unless otherwise specified, all data are presented as means \pm S.E. ANOVA, a $t$-test for unpaired data and the Mann-Whitney test were used when appropriate; the correlation study was evaluated with a simple regression test. $P<0.05$ was considered significant. Statistical analysis was carried out using Statview 5 for Windows software 1999 (SAS Institute Inc., Cary, NC, USA).

\section{Results}

Spontaneous leptin secretion by omental adipose tissue into the incubation medium was progressive in samples $(n=$ 137) of both sexes from 0 to $96 \mathrm{~h}$ (Fig. 1). In the $24 \mathrm{~h}$ periods analyzed, leptin secretion significantly increased until $48 \mathrm{~h}$ in samples from both sexes. Thereafter, the secretion was well preserved, but with no significant increase, indicating that the in vitro model reached a plateau in spontaneous leptin secretion (Fig. 1). In both the $24 \mathrm{~h}$ and $48 \mathrm{~h}$ periods leptin secretion was significantly higher in women than in men $(P<0.05)$ (Fig. 1). Analyzed as the integrated secretion (AUC as nanograms of leptin per $\mathrm{g}$ tissue $/ 48 \mathrm{~h}$ ) leptin secretion in female samples $(n=68 ; 2902 \pm 192)$ was significantly higher $(P<$ $0.05)$ than that in male samples $(n=69 ; 2566 \pm 261)$. Part of these results was previously reported (20).

In order to evaluate whether the adiposity of the donor may influence the spontaneous leptin secretion by the adipose tissue in vitro, a simple regression analysis was performed. As Fig. 2 shows, no correlation was observed in either sex between the BMI of the donors and leptin secretion in adipose samples, at $48 \mathrm{~h}$. Similar results were obtained at all other time periods analyzed (data not shown).

\section{Discussion}

Leptin plasma levels seem to reflect the net amount of body fat for a given individual although a good degree of variability for individuals with similar amounts of fat mass was evident (13-19). This strong variability demonstrates that besides the net amount of adipose reserves, circulating leptin levels also reflect other variables that are still not well clarified. Circulating leptin levels show clearcut, gender-based differences, with higher values in women than men, a fact that requires explanation. The fact that female adipose tissue secretes more leptin than male tissue might be explained by an intrinsic property of female adipocytes; alternatively it could be explained as a consequence of the different hormonal milieu which impinges upon female adipose tissue. In any case, the only way to clarify the point is to analyze leptin secretion in vitro, a state in which non-hormonal variables are implicated. This point is of foremost relevance, as we have previously demonstrated that female adipose tissue, 
but not male explants, change their rate of leptin secretion depending on the presence of gonadal and adrenal steroid hormones (20).

In this study, when spontaneous leptin secretion was assessed in vitro in a large group of non-stimulated samples, a clear-cut gender difference was observed, as spontaneous leptin secretion by omental adipose tissue of female donors was higher than that from men. This confirms a preliminary report in vitro with a small number of samples analyzed (20). As the gender difference vanished over time, it is possible that the action of certain steroid hormones (glucocorticoids, estrogens) could be still operative in vitro in the first $48 \mathrm{~h}$ of study, disappearing later on (20). If this were true, the gender differences would be due to either hormonal regulation or receptor characteristics of the tissues.

To the best of our knowledge, this is the first demonstration that leptin secretion is not related to the adiposity of the donors. Although not directly assessed, it is assumed that obese subjects have larger adipocytes than lean ones, and as the samples here presented were normalized by weight it should be expected that explants from obese individuals would contain fewer but larger adipocytes than tissue samples from leaner donors. This presumptive adipocyte size difference was not translated into differences in leptin secretion. This may be taken as indirect suggestion that the net amount of fat and not the size or number of the adipocytes is the relevant factor controlling the circulating leptin levels.

In conclusion, in vitro leptin secretion from a very large series of adipose tissue samples was significantly higher in women than in men, confirming the gender differences in basal leptin secretion previously reported (20). Adiposity of the donor did not affect weightnormalized in vitro leptin secretion, suggesting that is the net amount of fat and not the adipocyte size or number that is the variable conditioning plasma leptin levels. The adipose tissue cultures showed a clear-cut gender-based difference in leptin secretion, confirming the presence of a strongly different 'adipocyte sex'.

\section{Acknowledgements}

The work was supported by grants from the Fondo de Investigacion Sanitaria, the Spanish Ministry of Health and the Xunta de Galicia. R B is a recipient of a Dottorato di Ricerca course of the University of Rome 'La Sapienza', Chair of Endocrinology, School of Medicine, granted by the European Commission Structural Funds.

\section{References}

1 Zhang Y, Proenca R, Maffei M, Barone M, Leopold L \& Friedman JM. Positional cloning of the mouse obese gene and its human homologue. Nature 1994372 425-432.

2 Pelleymounter MA, Cullen MJ, Baker MB, Hecht R, Winters D, Boone T et al. Effects of the obese gene product on body weight regulation in ob/ob mice. Science 1995269 540-543.

3 Halaas JL, Gajiwala KS, Maffei M, Cohen SL, Chait BT, Rabinowitz
D et al. Weight-reducing effects of the plasma protein encoded by the obese gene. Science $1995269543-546$.

4 Campfield L, Smith F, Guisez Y, Devos R \& Burn P. Recombinant mouse OB protein: evidence for a peripheral signal linking adiposity and central neural networks. Science $1995269546-549$.

5 Considine RV, Considine EL, Williams CJ, Hyde TM \& Caro JF. The hypothalamic leptin receptor in humans: identification of incidental sequence polymorphisms and absence of the $\mathrm{db} / \mathrm{db}$ mouse and fa/fa rat mutations. Diabetes 199645 992-994.

6 Considine RV, Nyce MR, Kolaczynski JW, Zhang PL, Ohannesian JP \& Moore JHJr. et al. Dexamethasone stimulates leptin release from human adipocytes: unexpected inhibition by insulin. Journal of Cellular Biochemistry $1997 \mathbf{6 5} 254-258$.

7 Considine RV, Sinha MK, Heiman ML, Kriauciunas A, Stephens TW, Nyce MR et al. Serum immunoreactive-leptin concentrations in normal-weight and obese humans. New England Journal of Medicine 1996334 292-295.

8 al Shoumer KA, Anyaoku V, Richmond W \& Johnston DG. Elevated leptin concentrations in growth hormone-deficient hypopituitary adults. Clinical Endocrinology 199747 153-159.

9 Houseknecht KL, Mantzoros CS, Kuliawat R, Hadro E, Flier JS \& Kahn BB. Evidence for leptin binding to proteins in serum of rodents and humans: modulation with obesity. Diabetes $1996451638-1643$.

10 Klein S, Coppack SW, Mohamed Ali V \& Landt M. Adipose tissue leptin production and plasma leptin kinetics in humans. Diabetes 199645 984-987.

11 Sinha MK, Opentanova I, Ohannesian JP, Kolaczynski JW, Heiman ML, Hale J et al. Evidence of free and bound leptin in human circulation. Studies in lean and obese subjects and during shortterm fasting. Journal of Clinical Investigation 199698 1277-1282.

12 Ahima RS, Prabakaran D, Mantzoros C, Qu D, Lowell B, Maratos Flier $\mathrm{E}$ et al. Role of leptin in the neuroendocrine response to fasting. Nature $1996 \mathbf{3 8 2} 250-252$.

13 Casanueva FF \& Dieguez C. Neuroendocrine regulation and actions of leptin. Frontiers in Neuroendocrinology 199920 317-363.

14 Sierra-Honigmann MR, Nath AK, Murakami C, Garcia-Cardena G, Papapetropoulos A, Sessa WC et al. Biological action of leptin as an angiogenic factor. Science $1998 \mathbf{2 8 1} 1683-1686$.

15 Jin L, Burguera BG, Couce ME, Scheithauer BW, Lamsan J, Eberhardt NL et al. Leptin and leptin receptor expression in the normal and neoplastic human pituitary: evidence of a regulatory role of leptin on pituitary cell proliferation. Endocrinology 2000141 333-339.

16 Hamilton BS, Paglia D, Kwan AY \& Deitel M. Increased obese mRNA expression in omental fat cells from massively obese humans. Nature Medicine 19951 953-956.

17 Montague CT, Prins JB, Sanders L, Digby JE \& O'Rahilly S. Depotand sex-specific differences in human leptin mRNA expression: implications for the control of regional fat distribution. Diabetes 199746 342-347.

18 Leal-Cerro A, Considine RV, Peino R, Venegas E, Astorga R, Casanueva FF et al. Serum immunoreactive-leptin levels are increased in patients with Cushing's syndrome. Hormone and Metabolic Research 199628 711-713.

19 Peino R, Piñeiro V, Gualillo O, Menendez C, Brenlla J, Casabiell X et al. Cold exposure inhibits leptin secretion in vitro by a direct and non-specific action on adipose tissue. European Journal of Endocrinology 2000142 195-199.

20 Casabiell X, Piñeiro V, Peino R, Lage M, Camiña J, Gallego Ret al. Gender differences in both spontaneous and stimulated leptin secretion by human omental adipose tissue in vitro: dexamethasone and estradiol stimulate leptin release in women, but not in men. Journal of Clinical Endocrinology and Metabolism $1998 \mathbf{8 3} 2149-2155$.

21 Tome MA, Lage M, Camiña JP, García-Mayor RV, Dieguez C \& Casanueva FF. Sex-based differences in serum leptin concentrations from umbilical cord blood at delivery. European Journal of Endocrinology 1997137 655-658.

Received 29 May 2000

Accepted 27 July 2000 